\title{
Ancient Topography Research in the Territory of Rodi-Milici (Messina): Preliminary Results
}

\author{
Caterina Ingoglia \\ University of Messina, Department of Ancient and Modern Cultures, Messina \\ email: caterina.ingoglia@unime.it
}

\section{Giuseppe Scardozzi}

National Research Council of Italy - Institute for Archaeological and Monumental Heritage, Lecce email: g.scardozzi@ibam.cnr.it

\section{Abstract}

The paper concerns a research project carried out since 2011 by the Department of Sciences on the Antiquity of the University of Messina and the Institute for Archaeological and Monumental Heritage of the Italian National Research Council. The project is aimed at the reconstruction of the ancient topography of the territory of the modern village of Rodi-Milici, in the Province of Messina.

The first campaign of systematic archaeological and topographical surveys, using a differential GPS system and a Laser Scanner, were performed in the hills to the west and south-west of the two villages, in particular on the large plateau between Monte Ciappa, to the north, and Pizzo Cocuzza, to the south. The investigated area was identified by L. Bernabò Brea, at the beginning of the 1950s, with the site of the ancient city of Longane. It had a strategic location for the control of the valleys of the Patri and Mazzarrà rivers (respectively to the east and west of the investigated areal which constituted important routes of connection and traffic between the Tyrrhenian coast, the Monti Peloritani area and the lonian coast of Sicily.

The recent research, in integration with previous studies, acquired new data about the Archaic settlement that had an organisation strictly integrated to the topographical context and a structure different from traditional Greek colonies. The settlement on the plateau did not have a regular plan but seems organised into quite well distinguished inhabited, productive and sacred areas, while other areas are free of structures. It was protected by the two fortified hills (Monte Ciappa and Pizzo Cocuzzal which controlled the natural entrances to the plateau from north and south; the necropolises were located to the north-east and south of these hills, along the principal ways to arrive to the settlement.

Keywords: Archaeological survey; Longane; Monte Ciappa; Archaic period; Patrì river valley

\section{Archaeological and Topographical Sur- veys in the Territory of Rodi-Milici}

Since 2011 the former Department of Sciences on the Antiquity of the University of Messina Inow Department of Ancient and Modern Cultures) and the Institute for Archaeological and Monumental Heritage of the Italian National Research Council, in Lecce, have carried out a research project aimed at the reconstruction of the ancient topography of the territory to the south-west of the Greek colony of Mylae and to the south-east of the other Greek city of Tindari, in particular in the area of the modern villages of Rodi-Milici, in the Province of Messina. The study area, located on the hills overlooking the Tyrrhenian coast between Milazzo and Tindari, is characterised by important Protohistoric necropolises and, in particular, by interesting evidence of connections between Greeks and indigenous peoples from the Late Archaic period to the Hellenistic Age. 


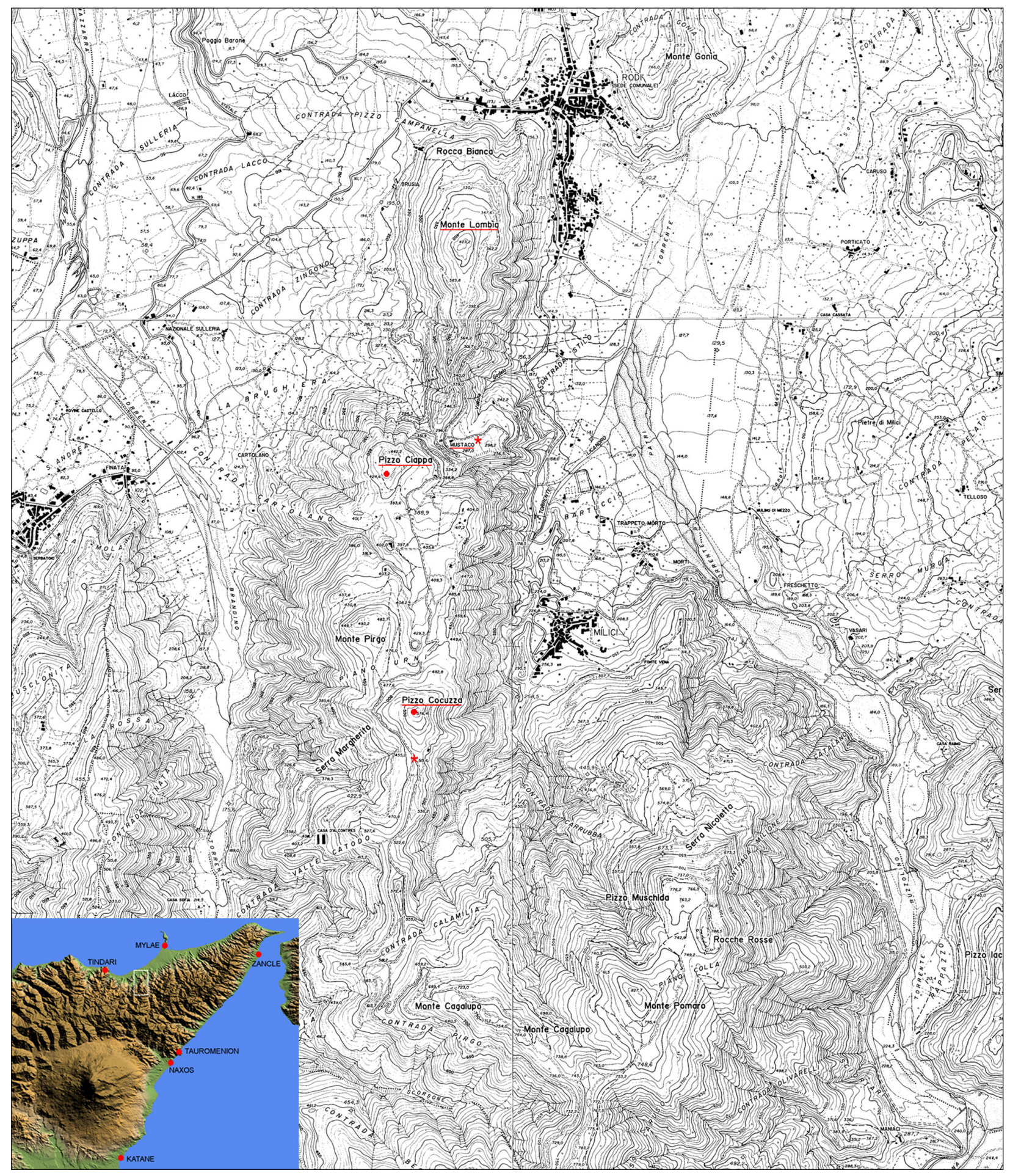

Fig. 1. General map of the investigated area: the fortifications on Monte Ciappa and Pizzo Cocuzza and the two necropolises (asterisks) to the north and south are highlighted. In the square, DEM shows the location of the study area.
Despite the very fragmented archaeological research conducted along the Tyrrhenian slopes of the Peloritani Mountains, the territory of Rodi-Milici, west of the Patri river, which runs alongside the villages to the east, has considerable potential information for the reconstruction of the dynam- 
ics of the ancient settlement pattern and, more generally, the history of north-eastern Sicily from Prehistoric times.

First archaeological research in this territory was performed at the beginning of 20th century by P. Orsi, who discovered a few Archaic tombs in the Mustaco plain, west of Rodi-Milici (Bernabò Brea, 1975: 9; 2000: 34; Orsi, 1915: 4, 8-10). Orsi supposed that in the area was 'se non di una città vera e propria, di una grande borgata di mezza montagna' (Orsi, 1915: 16). The investigations resumed between the end of 1940s and the beginning of 1950s thanks to a local scholar, D. Ryolo di Maria, who reported the presence of archaeological remains (in particular, fortifications) south of the Mustaco plain; they were related to the ancient city of Longane, mentioned in the literary (Diod. Sic. 22.13; Polyb. 1.9.7), epigraphic and numismatic sources. The area north of Rodi-Milici was considered part of the field for the Longano battle (269 BC) between the Syracusans of Hieron II and the Mamertines of Cione; moreover, the Patrì River was identified with the Longano River (Ryolo di Maria, 1950-1951: 347-48; 1956: 255-56; Ryolo di Maria \& Bernabò Brea, 1967: 7-37).

With the information collected by Ryolo di Maria, Bernabò Brea programmed, with G.F. Carettoni and M. Cavalier, excavation campaigns and proposed the results to the scientific community, highlighting for the first time the rich archaeological potential of the whole area around Rodi-Milici. During the excavations in 1951-1952, a few chamber tombs a grotticella of the Ancient Bronze Age were discovered immediately to the north-east of Rodì-Milici (Bernabò Brea, 1967: 208-209, 239-51) along the slopes of Monte Gonia, where, in the sites named Contrada Grassorella and Contrada Paparini a large necropolis of the Iron Age was excavated (Bernabò Brea, 1967). In the last one were found materials comparable with that from the not far necropolis discovered by Orsi in the site named Contrada Uliveto-Risica, in the territory of Barcellona-Pozzo di Gotto, along the eastern slope of the Patrì River (Cavalier, 1992: 130; Orsi, 1915): both necropolises are dated in the first three quarters of the eighth century BC (Bernabò Brea, 1967:
236-37; Cavalier, 1992: 131-32).

There are no known settlements relating to these necropolises, but we must emphasis that both have allowed the recognition of the existence of Prehistoric and Proto-historic phases, at that time (1950s) almost unknown and nowadays still being defined, in the north-eastern sector of Sicily. In particular, the chamber tombs a grotticella of Monte Gonia revealed a prescence during the so-called "Ausonius III"; this period is a great unknown in the stratigraphies of the Aeolian Islands and Milazzo (Bernabò Brea, 1967: 230-39; Cavalier, 1992: 131-32), it is now attested, in a very fragmentary and sometimes poorly defined way, in a few other upland sites overlooking the Tyrrhenian coast of Sicily (Ingoglia, 2012b: 117).

At the beginning of 1950s, Bernabò Brea unearthed the remains of a fortification on Monte Ciappa, west of Rodi-Milici (Bernabò Brea, 2000: 18-34). According to the scholar, it would have occupied the acropolis of the city of Longane and the tombs discovered by Orsi in Mustaco plain would belong to the same settlement, together with the structures of a sacred area at the western edge of the large plateau below Monte Ciappa, in a south direction (Bernabò Brea, 2000) and another small fortress on Pizzo Cocuzza o Ferri, further south (Bernabò Brea, 2000: 14-15).

The research in the area resumed only at the end of the 1990s and was limited to identifying a rural settlement of the Hellenistic Age on the top of Mount Gonia (Siracusano, Campagna \& Falcone, 2000: 8-40). Regardless of the problem of locating the indigenous town of Longane, the existence of which is indicated by the presence two silver and a bronze caduceus, of unknown origin, in the collections of the British Museum (Ingoglia, 2012b: 179), it is evident that the fortifications on Monte Ciappa and Pizzo Cocuzza have to be referred to an indigenous population that, from the Late Archaic period and during most of the Classical Age, felt a strong need to protect the entrances of the waterways from communication with the hinterland. In the 1970s, the discovery of numerous Iron Age tombs and fortifications of the Late Archaic period in the territory of Barcellona-Pozzo di Gotto, west 

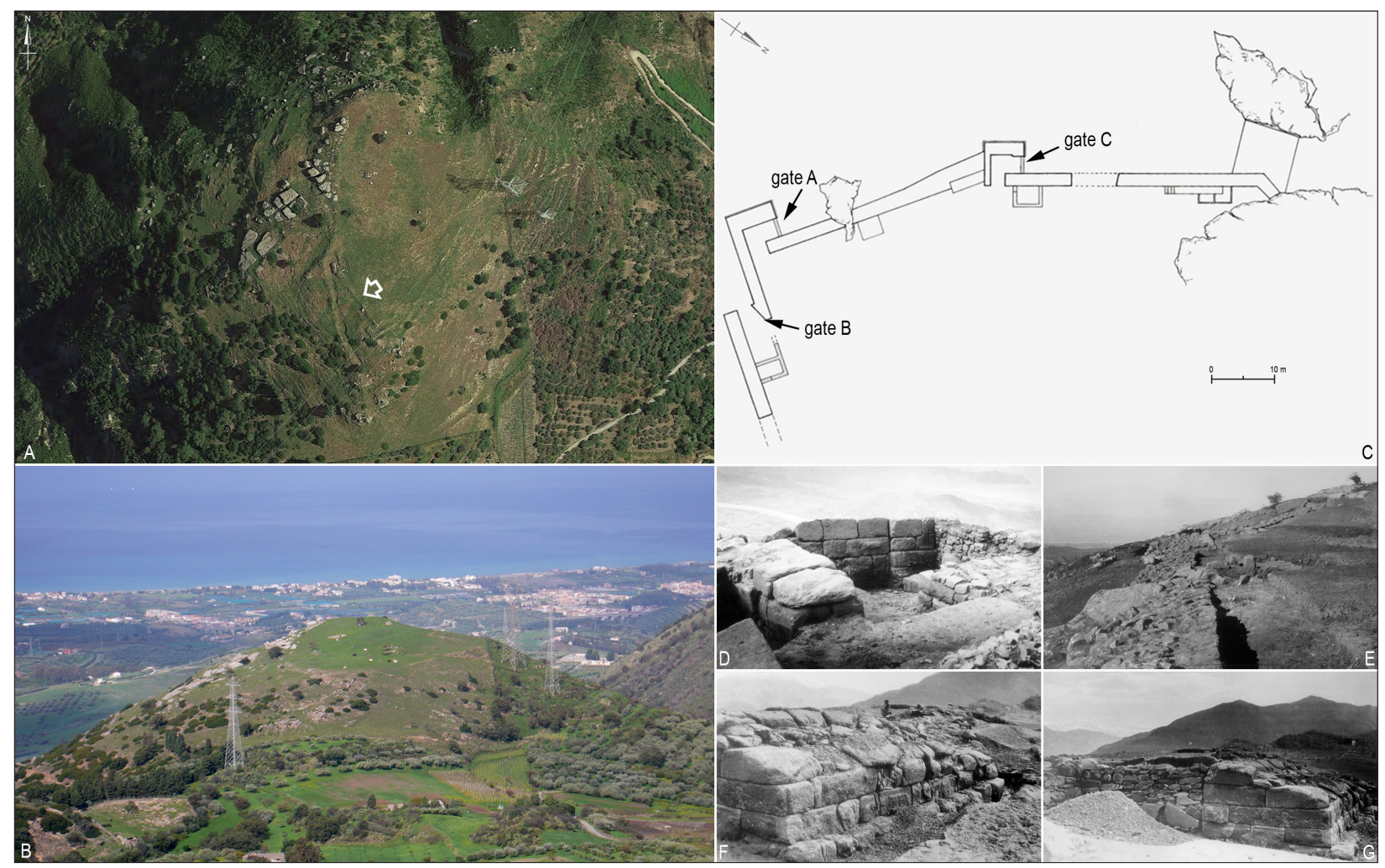

Fig. 2. Monte Ciappa: A, vertical view from Google Earth taken in 6/6/2014 (the arrow indicates the remains of the fortification); $B$, general view from south; $C$, general plan of the fortifications excavated by L. Bernabò Brea at the beginning of 1950s; $D$, the internal side of the $C$ gate (view from south-east); $E$, the wall between the gates-towers $A$ and $C$; $F$, the $C$ gate from north-west; $G$, the $C$ gate from north ( $C-G$ from Bernabò Brea, 2000).

of Rodi-Milici, beyond the Patrì river (Bonanno, 1997-1998; 2000; Cavalier, 1992: 127-30; Voza, 1976-1977), reinforces the hypothesis of the importance that the area had in Antiquity. In fact, both the areas west (territory of Barcellona-Pozzo di Gotto and Castroreale) and west of Patrì River (territory of Rodi-Milicil are frequented during the first three quarters of the eighth BC. Later, after a break of about two centuries, indigenous populations settled with a capillary system of small forts, the range is not yet well known.

Archaeological research of the 20th century observed only some geographical aspects of the

Rodi-Milici area (Bernabò Brea, 2000: 11-12), quite apart from the entire environmental, geological and morphological framework of this territory, which is of great significance for the reconstruction of its history. Patri River, that cuts along a north-south direction the Peloritani, has the historical and geographical value of being an important route for the connection from one side to the other of the mountains and from the Ionian Sea to the Tyrrhenian Sea and vice versa (Ingoglia, 2012a). The convenient and wide open river valley allowed a quick and easy passage during the warm season; in the bad season, when the river was threatening and dangerous, and with to large amount of debris, the negotiable ways would have been the ridges of the mountains, certainly linked to the ancient transhumance routes.

Using a landscape archaeology approach, the evaluation of the environmental resources allowed a better understanding of the ancient settlement pattern. In fact, it is evident that the small forts were at the entrance of a river valley along which are some of the most important, because even 
unique, mining areas of Sicily, i.e. those of Bafia-Castroreale and Fondachelli-Fantina-Novara; moreover, not far to the east, on the watershed of the Peloritani, is the mining area of Fiumedinisi, where excavations in the 1970s found blast furnace slag dated to the Eneolithic, documenting a very old knowledge by man of the environmental resources of the area (Ingoglia, 2012b: 184-86). So, in addition to the more obvious resources of the mountain and river environment, this landscape presents a very important mineral resource.

Using a multidisciplinary approach typical of landscape archaeology, the study area appears rich in prospects for research. In fact, we believe that the issues proposed by the archaeological research, which was conducted until now more or less systematically, are multiple and all worthy of further investigation.

The settlements that used the necropolises of Monte Gonia are not known. Furthermore, at the present state of research, any settlement pattern of the Iron Age that can serve as a reference for the research on this area of north-eastern Sicily, is not known. Also we do not know if the necropolises of Monte Gonia were used until a phase immediately before the arrival of the Greek-Euboean colonists of Zancle or if the end of the indigenous settlement was determined by Greeks (Bacci, 1999: 255-56).

The study of the settlement dynamics in this territory, started with surveys and excavations in areas of high archaeological potential, will help us to understand if, in the early centuries of the life of Zancle, this area of northern Sicily was controlled exclusively by Calcidise Greeks or whether there was the persistence of the indigenous element (in agreement or in conflict with Greeks) over the half/third quarter of the eighth century BC.

According to the available evidence, we can say that in the area, between the Late Archaic and the Classical Age (sixth-fifth centuries BC), important needs of defense determined a new dynamic in the settlement of indigenous peoples: in particular, the rise of defensive settlements organised probably into a military "system" or to control the access to the river valley. The need for control could depend first, on the importance of the river as a communication route or, secondly, on the need for defense and the exploitation of the mineral resources of the area. Within the framework of research activities, we are trying to clarify the organisation and purpose of these fortification systems, first in the Rodi-Milici territory. These are territorial infrastructures probably external to an important site (Longane?) aimed at protecting the access to the territory gravitating toward the waterway, defending it from people coming from the coast.

Although the remains of material culture found in the small forts and the types of tombs adopted suggest that the inhabitants were indigenous peoples, perhaps in contact with Greeks, we do not have full knowledge of the nature of their relationships (Ingoglia, 2012b: 181-82).

From this brief review of the main themes that characterise the part of our research on the pre-Greek and Greek period it is clear that one of the primary goal of the project is to focus on a diachronic analysis of relations between the two worlds, indigenous and Greek. To this end, we have reconsidered the historical interpretation of the archaeological evidence, which, if seen in the context of the landscape of belonging, is even more problematic.

The ultimate goal of the research project is the historic reconstruction of the territories of Rodi-Milici, Barcellona-Pozzo di Gotto and Castroreale, as well as the enhancement in value of the entire area investigated, through the realisation of an archaeological map where all evidence documented during the archaeological field walking is georeferenced, both the known sites and the new ones. About the employment and the function of each site, we defer to the results coming from the archaeological excavations, which, again for reasons related to the difficult morpho-evolutive dynamic of the area, in some cases require the application of specific technologies and preventive studies.

C.I. 

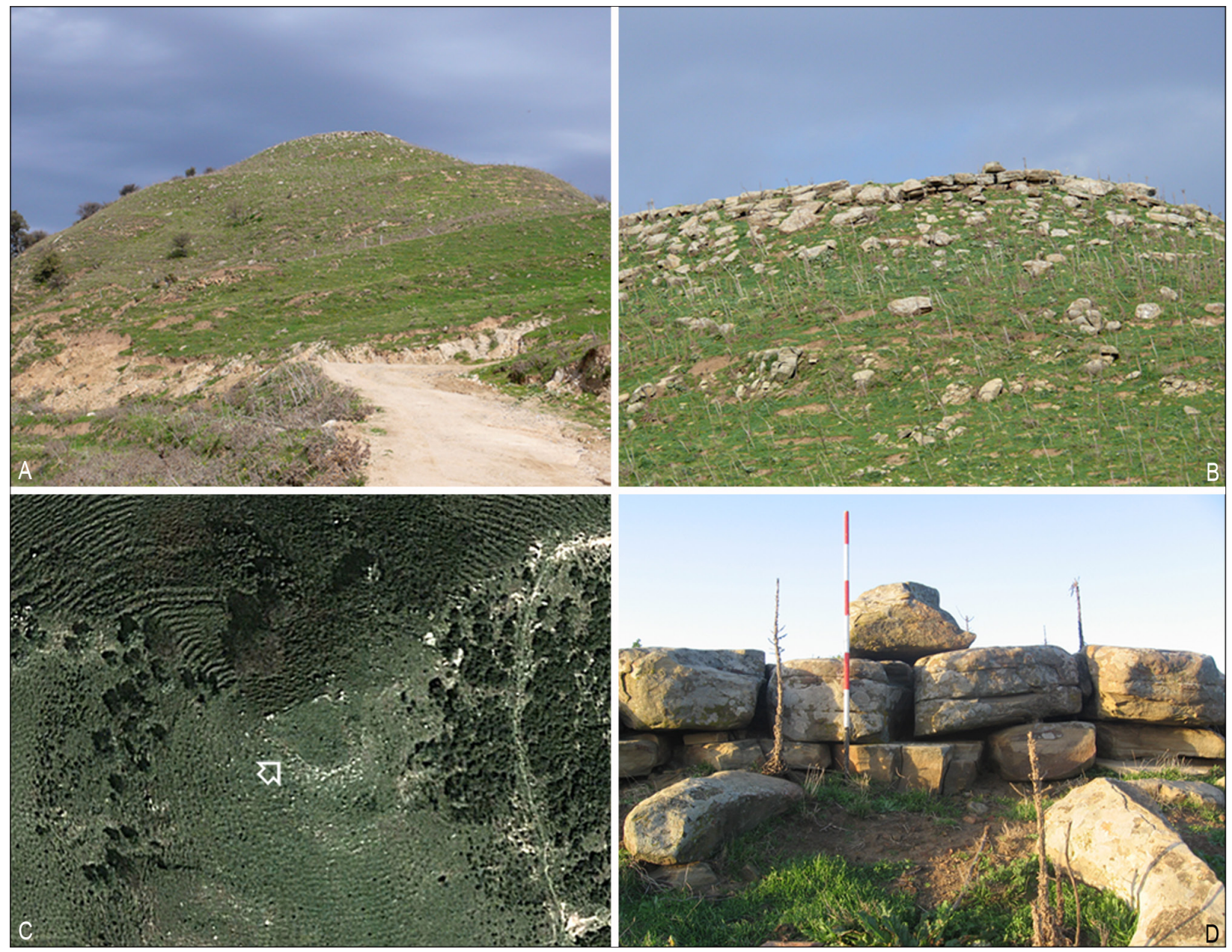

Fig. 3. The fortification on Pizzo Cocuzza: A, general view from south; $B$, top of the hill; $C$, vertical view from a WorldView-2 satellite image (1-4-2012); D, detail of the preserved wall.

\section{The Field Walking: Preliminary Results}

The first campaign of archaeological and topographical surveys, performed in November 2011 using a differential GPS system and a Laser Scanner (in cooperation with the CNR Institute for the Chemical and Physical Processes, Messina) was aimed at the investigation of the territory between the Patrì River and the Brandino stream, a tributary of the Mazzarrà River (respectively to the eastern and western boundaries of the area), near the villages of Rodi and Milici, about

$4 \mathrm{~km}$ south of the stretch of the Tyrrhenian coast between Milazzo and Tindari (fig. 1). In particular, the systematic field walking concerned the hills immediately to the west and south-west of the two villages: from the north, Monte Lombia (m 423 AMSL), Pizzo Ciappa (m 442 AMSL), Monte Pirgo (m 495 AMSL), Pizzo Cocuzza (m 576 AMSL). Between Pizzo Ciappa to the north and Monte Pirgo and Pizzo Cocuzza to the south there is a plateau that is until $450 \mathrm{~m}$ large lalong the east-west axis) and 1,300 $\mathrm{m}$ long (in north-south direction); it is about $m$ 390-430 AMSL. The hills and the eastern and western edges of the plateau are characterised by very steep slopes that descend in east and west direction toward the Patrì River and the Brandino stream and in north direction toward the coastal plain. To the south, the archaeological surveys were stopped on the ridge named Serra 
Margherita, located between Pizzo Cocuzza lto the north) and Contrada Calamita, Monte Cagalupo and Contrada Pirgo (to the south).

Overall the investigated area has a surface of about 400 hectares. The surveyed area consists mainly of grading lands and woods, while the cultivated fields are very few. So, the "archaeological visibility" of the investigated area is not very good. Nevertheless, the research has allowed us to acquire new data on the topographical organisation of the ancient settlement in this area, in particular during the Archaic period. It was naturally fortified by the orography of the site and had a strategic location for the control of the valleys of the Patri and Mazzarrà rivers, which constituted important routes (in particular the first one) for connections and traffic between the Tyrrhenian coast and the interior territories of Monti Peloritani; on a large scale, the Patrì (Ingoglia, 2012a: 250-57) and, to a lesser extent, Mazzarà (Burgio, 2005: 209; Uggeri, 2004: 207). These river valleys allowed the connection between the Tyrrhenian coast and the north-eastern Ionian coast of Sicily lterritories of Naxos and Tauromenion).

The archaeological surveys allowed us to acquire new and very interesting data for the reconstruction of the ancient settlement pattern in the area, where Ryolo di Maria and Bernabò Brea identified the ancient city of Longane (see above); but it is still an hypothesis. The settlement had an organisation strictly integrated to the topographical context and a structure that appears different from traditional Greek colonies. It was characterised by two fortified hills that controlled the natural entrances to the plateau from north and south.

The northern fortress was on the top of Monte Ciappa (fig. 2), where the remains of an Archaic fortification are. It was excavated by Bernabò Brea at the beginning of 1950s (Bernabò Brea, 2000: 18-34; Carettoni, 2000b). These remains are preserved along the south-western edge of the fortress and consist of a dry-stone wall built with two facings in large square blocks, which also includes a tower (named B) and two gates-towers (named $A$ and $C$ ). According the morphology of the site, it is possible to suppose that the wall enclosed the western and southern edges of the top of the hill, while the northern and eastern edges would not need fortifications due to the very steep slopes. So, the fortress had an overall surface of about 1 hectare; the entrances were from south-west, where the slope is less steep. Moreover, during the excavations proto-historic pottery was found which document the occupation of the site during this period. The fortress of Monte Ciappa was very important in controlling the northern entrance to the plateau and the settlement area; it also allowed control of the coastal plain and the northern sectors of the Patrì and Mazzarrà river valleys.

The southern fortress was on the top of the conic-shape hill named Pizzo Cocuzza, where are preserved the remains of a small trapezoidal-shape enclosure that was built using large irregular blocks (fig. 3); these dry-stone walls are preserved only for one, two or three rows of blocks. This fortification is very small la fortino in Bernabò Brea, 2000: 14); in fact, it had a perimeter of about $90 \mathrm{~m}$ and enclosed a surface of about 550 $\mathrm{m}^{2}$. Its purpose is only the control of the southern entrance to the plateau and the settlement area, thanks to the direct control of the ancient road coming from the south on the narrow ridge of Serra Margherita, characterised by very steep slopes along the eastern and western edges. Six stratigraphic trenches, which were excavated by Bernabò Brea in 1951, documented the occupation of this site during the Archaic period, but also proto-historic pottery was found, proving the occupation of the top of the hill during this period.

More to the north of Monte Ciappa, Monte Lombia was a strategic point for the control of the coast plain, the river valleys and northern access to the site. On the top of this hill are some rock cut structures and scarce remains of walls with uncertain chronology, but probably linked to the ancient settlement; during surveys carried out in the early 1950s on the hill, fragments of pottery of the Early Bronze Age were found.

In the investigated area, the settlement of the Archaic period was organised on the plateau between Monte Ciappa and Pizzo Cocuzza (fig. 4) and had an irregular shape and a surface of about 


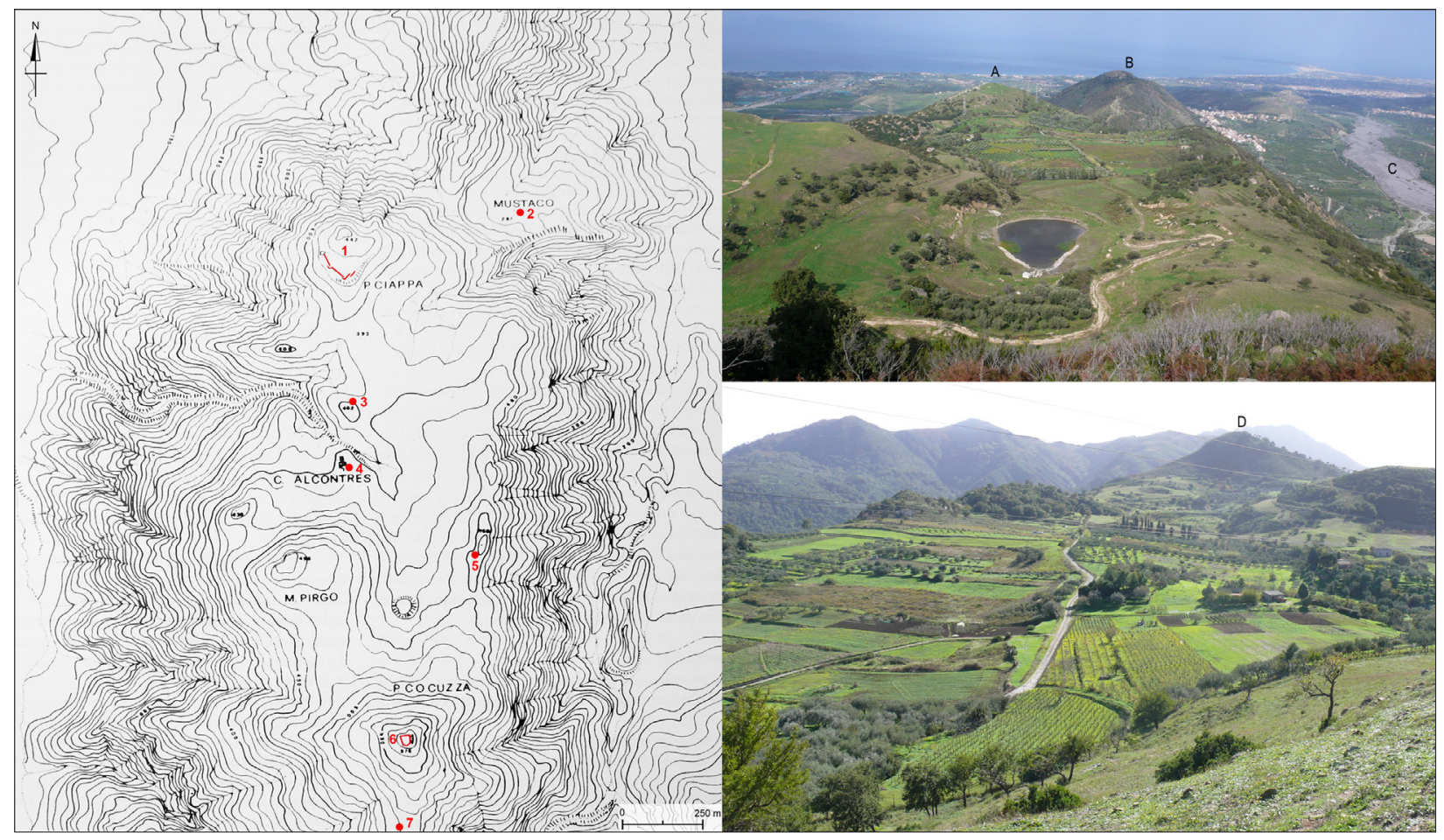

Fig. 4. General map of the settlement area (base map from Bernabò Brea, 2000): 1) necropolis of Mustaco, 2) fortification on Monte Ciappa, 3) remains of walls, 4) structures near Casina Alcontres probably related to a sacred area, 5) structures, 6) small fortress on Pizzo Cocuzza, 7) necropolis along the road directed toward south. Two views of the plateau from the south (top right): Al Monte Ciappa, B) Monte Lombia, C) Patrì River; and the north (bottom right): D) Pizzo Cocuzza.

45 hectares. It is limited by the two fortified hills to the north and south, and by Monte Pizzo to the south-west, while the eastern and western boundaries are the steep slopes that descend towards the Brandino stream (to the west) and the Licandro stream, a tributary of the Patri River (to the east). The plateau is not in plain, but the western and eastern sides are higher than the central sector; moreover the site is rich in springs and water, which can be found at a shallow depth deep. The preliminary results of the recent research, integrated to previous studies and investigations, in particular the numerous stratigraphic trenches excavated at the beginning of 1950s by Bernabò
Brea (2000: 15-16), confirmed that the settlement did not have a regular layout, but seems organised in quite well distinguished inhabited, productive and sacred areas, while other areas are free of structures and probably were also used for vegetable gardens. Along the westernmost side of the plateau, at the northern slope of Monte Pirgo, near Casina Alcontres, there are the remains of a narrow paved road and three Archaic buildings in blocks, which were excavated in 1951-1952 and probably belonged to a sacred area (Bernabò Brea, 2000: 16-18; Carettoni, 2000a). About $200 \mathrm{~m}$ north of Casina Alcontres, during the recent surveys, some remains of dry-stone walls built using large square blocks were found; they are partially collapsed and could belong to other fortifications along the western edge of the plateau. In the same area, at the beginning of 1950s, the remains of three small quadrangular buildings lone of which with an apsel were found; they were dated to "late age" and linked to a tradition of the possible presence in this site of a church dedicated to San Biagio (Carettoni, 2000a: 37). Moreover, other drystone structures of uncertain function were found at the eastern limit of the plateau. 


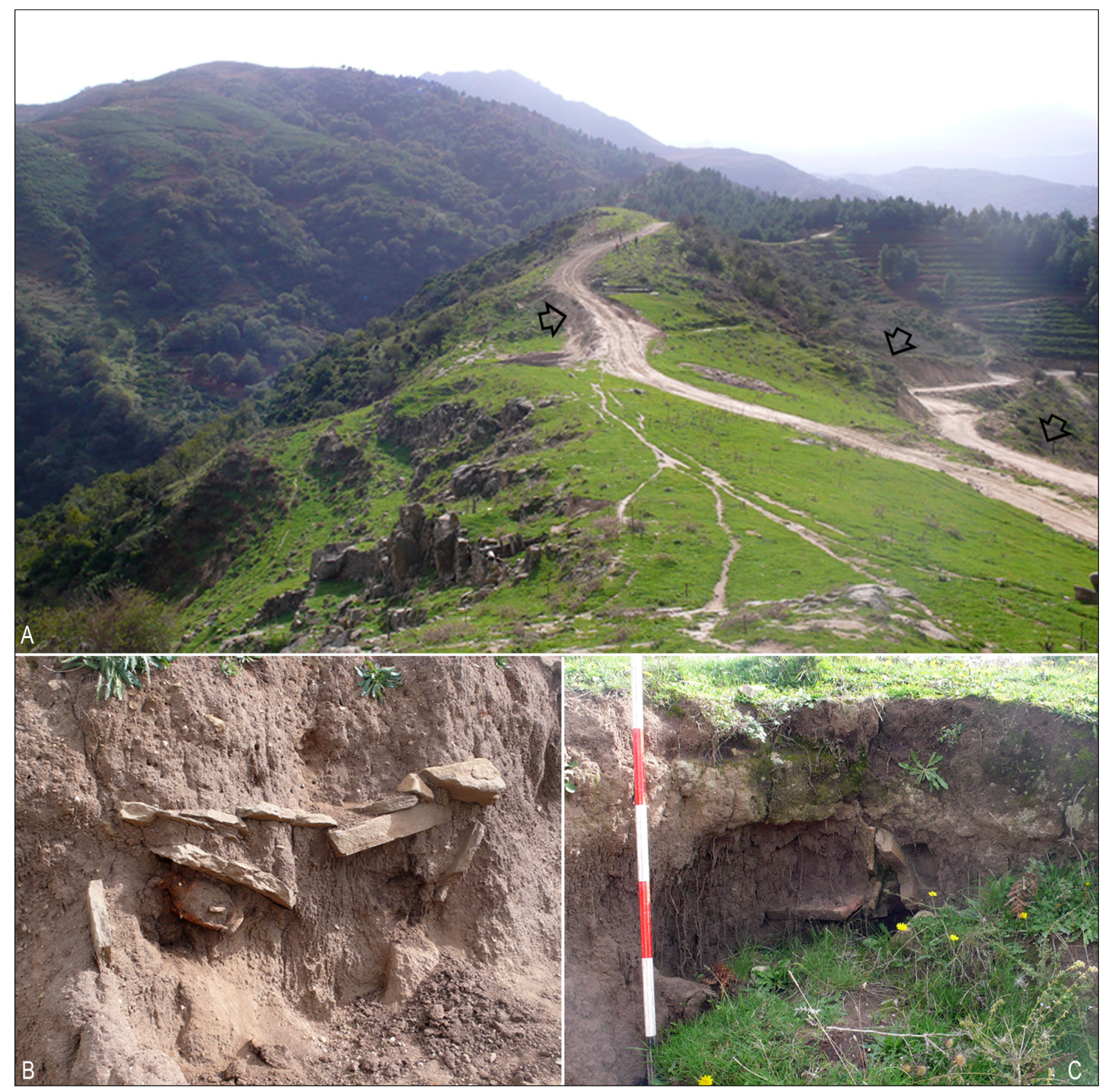

Fig. 5. Necropolis to the south of Pizzo Cocuzza: Al general view from north (the arrows indicate the location of the tombs), B-Cl details of two pit graves cut by recent mechanised works.

The research has also highlighted that the necropolises were located outside the plateau, to the north-east and to the south of the two fortified hills. The first funerary area is in the site named Mustaco, a small plain (about m 290 AMSL) at the north-eastern outermost slope of Pizzo Ciappa (see above). Here, in the 1910s, Orsi excavated an Archaic necropolis with pit graves built using narrow slabs and covered by tiles and cobbles (Orsi, 1915: 4, 8-10); a limited number of other excavations were carried out by Bernabò Brea at the beginning of the 1950s (Bernabò Brea, 1975: 9; 2000: 34). This necropolis is along the route that constitutes the northern access to the plateau where the settlement lies; this route descends to the Patri River valley, in the area named Contrada 
Stilo, south of the modern village of Rodi. From the same Mustaco area another route goes in a north direction and arrives on the top of Monte Lombia. Moreover, the recent archaeological field walking allowed the identification of the southern necropolis. It was located at the southern slopes of Monte Cocuzza, along the road that reached the settlement from the interior mountains, running on a narrow ridge (fig. 5). Here, some pit graves built using narrow slabs were discovered; they were cut by recent mechanised works, along both the western and eastern sides of the road. In these tombs, that are of the same typology of the graves in the Mustaco area, pottery of the sixth-fifth centuries $\mathrm{BC}$ was found.

Therefore, the first field walking campaign allowed the acquisition of very interesting data about the settlement of the investigated area during the Archaic period. No data about the Protohistoric occupation of the area were found. This question is strictly linked to the identification of the settlement or settlements that used the necropolises on Monte Gonia (m 266 AMSL), located about 600 m north-east of Monte Lombia, which is separated by the cleft where the village of Rodi lies. In these necropolises, located in the western side of the Patrì River valley, a few small chamber tombs la grotticellal with Ancient Bronze Age materials and some Iron Age graves were found by Bernabò Brea again at the beginning of the 1950s. So, one of the targets of the next field walking campaign could be the identification of the Protohistoric settlement pattern in the study area. Finally, another task of the next archaeological surveys could be the extension of the investigation in the hills south of Serra Margherita, with the aim to reconstruct the settlement pattern of this area that provided access to the Peloritani Mountains.

G.S.

\section{Acknowledgements}

The authors wish to thank Dr. Alessio Toscano Raffa (University of Messina), Dr Ilaria Miccoli and Dr Veronica Randino (IBAM-CNR) for their cooper- ation during the archaeological and topographical surveys.

\section{References}

Bacci GM, 1999: Siti e insediamenti nell'area peloritana e nella cuspide nord-orientale della Sicilia, in Barra Bagnasco M, De Miro E \& Pinzone A led.), Origine e incontri di culture nell'antichità. Magna Grecia e Sicilia. Stato degli studi e prospettive di ricerca. Atti Incontro di Studi, Messina 2-4 dicembre 1996, Messina, 249-58. DiScAM, Messina.

Bernabò Brea L, 1967: La necropoli di Longane, Bullettino di Paletnologia Italiana, 76, 181-254.

Bernabò Brea L, 1975: Che cosa conosciamo dei centri indigeni della Sicilia che hanno coniato monete prima dell'età di Timoleonte, in Le emissioni dei centri siculi fino all'epoca di Timoleonte e i loro rapporti con la monetazione delle colonie greche di Sicilia. Atti IV Convegno del Centro Internazionale di Studi Numismatici, Napoli, 9-14 aprile 1973: 3-52. Istituto italiano di numismatica, Roma.

Bernabò Brea L, 2000: Longane, Quaderni di Archeologia - Università di Messina, 1(1), 7-34.

Bonanno C, 1997-1998: Recenti esplorazioni a Pizzo Lando nel territorio di Barcellona P.G., Kokalos, 43, 44 , vol. 2, 1, 375-99.

Bonanno C, 2000: Nuovi ritrovamenti di età preistorica nella costa settentrionale messinese, Sicilia Archeologica, 33, 98, 375-99.

Burgio A, 2005: La viabilità in età greca e romana in Sicilia, in Ghedini F, Bonetto J, Ghiotto AR \& Rinaldi F (ed.), Lo stretto di Messina nell'antichità: 205-13. Società Stretto di Messina, Edizioni Quasar, Rome.

Carettoni GF, 2000a: Appendice n. 1. Longane. Costruzioni accanto alla Casina Alcontres, Quaderni di Archeologia - Università di Messina, 1(1), 35-37.

Carettoni GF, 2000b: Appendice n. 2. Acropoli di Monte Ciappa. Relazione descrittiva in data 11 febbraio 1952, Quaderni di Archeologia - Università di Messina, 1(1), 39-41.

Cavalier M, 1992: Milazzo, in Bibliografia Topografica della Colonizzazione Greca in Italia e nelle Isole Tirreniche, vol 10, Siti: Messina-Monte Sannace: 11540. Scuola normale superiore, Pisa/ École française 
de Rome, Rome/Centre J. Berard, Naples.

Ingoglia C, 2012a: La valle del Patrì: un corridoio obbligato tra Tirreno e lonio?, in Calderone A (ed.), Cultura e religione delle acque. Atti del Convegno interdisciplinare "Qui fresca l'acqua mormora...."

(S. Quasimodo, Sapph fr. 2,5), Messina, 29-30 marzo 2011: 247-69. Giorgio Bretschneider, Rome.

Ingoglia C, 2012b: Archeologia dei paesaggi lungo la valle del Patrì (Messina): un progetto di ricerca, in Bergemann J (ed.), Griechen in Übersee und der historische Raum. Internationale Kolloquium, Universität Göttingen, 13-16 Oktober 2010, Leidorf: 175-86. Marie Leidorf GmbH, Rahden/Westf.

Orsi P, 1915: Necropoli sicula a Pozzo di Gotto in quel di Castroreale, Bullettino di Paletnologia Italiana, 41, 1-16.

Ryolo di Maria D, 1950-1951: Il Longano e la sua battaglia, Archivio Storico Siracusano, 3-4, 347-88.

Ryolo di Maria D, 1956: Ubicazione della sicula città di Longane, in Atti del VII Congresso nazionale di storia dell'architettura, Palermo, 24-30 settembre 1950: 255-56. Tipografia V. Bellotti, Palermo.

Ryolo di Maria D \& L Bernabò Brea 1967: Longane. Contributo alla conoscenza della città di Longane in occasione della celebrazione del $20^{\circ}$ anniversario dell'autonomia comunale, Stab. grafico G. Panta \& figlio, Patti.

Siracusano A, B Campagna \& D Falcone 2000: Resti di un complesso rurale ellenistico sul Monte Gonia presso Rodì Milici, Quaderni di Archeologia-Università di Messina, n.s. 1(1), 7-40.

Uggeri G, 2004: La viabilità della Sicilia in età romana, Congedo, Galatina.

Voza G, 1976-1977: Barcellona-Monte S. Onofrio, Kokalos, 22, 24, 579-81. 
